\title{
ENTRE OLHARES
}

\author{
O que era fundamentalmente invisivel se \\ oferece, subitamente, à claridade do olhar, em um \\ movimento aparentemente tão simples, tão \\ imediato, que parece a recompensa natural de \\ uma experiência bem realizada (...) Mas é preciso \\ inverter a análise: são as formas de visibilidade que \\ mudaram. \\ Michel Foucault
}

A noção de revista pode ser pensada como um olhar novamente, como um re-ver alguns fatos, conceitos ou pensamentos. A RESAFE em seu quarto número, rumo a seu segundo ano de vida vem tentando cada vez mais um re-ver, uma re-vista das interfaces entre a filosofia e a educação na América do Sul.

$\mathrm{Na}$ tentativa de criar este espaço de interlocução e encontros textuais, pudemos ver aparecer vários textos-olhares que acabam por colocar em contato experiências diferentes sobre os modos de relação entre as diversas experiências filosóficas e as diversas experiências educacionais - que mesmo tornadas conceitos, não se desligam das experiências que as articulam.

Este quarto número tenta traz algumas leves modificações na estrutura da revista que objetivam uma melhor navegação por ela. O menu que antes era horizontal, agora é vertical, possibilitando a inserção de novos itens no índice da revista. Inserimos um enlace direto para a página das normas de publicação da revista para facilitar o acesso dos leitores e possíveis colaboradores às instruções de organização formal dos textos. $\mathrm{O}$ endereço de correio eletrônico de contato da revista também foi modificado. A seção de relatos foi renomeada para "Experiências", com o objetivo de estender os textos que reflitam sobre experiências práticas, no sentido de que algumas elaborações teóricas baseadas a partir de experiências concretas também possam ser articuladas como vinculadas a essas práticas, isso sem descartar os relatos de experiências sem maiores elaborações teóricas.

Nesta primeira edição da seção renomeada, trazemos um dossiê sobre o Projeto Filosofia na Escola, da Faculdade de Educação da Universidade de Brasília, que em 
cerca de oito anos vem trabalhando com escolas da rede pública de ensino do Distrito Federal (Brasil). Eu mesmo, que estou ligado a este projeto a sete anos, vejo que depois da publicação do livro Filosofia na Escola Pública pela Editora Vozes de Petrópolis (RJBrasil), no ano de 2000 - que contava a experiência dos primeiros anos do projeto este dossiê aparece como uma outra possibilidade, agora para toda a América do Sul, para que o projeto esteja entre olhares, sendo visto e discutido. Esta pode ser uma oportunidade de estabelecer contatos com outros olhares, com outras experiências $e$ reflexões sobre a atividade filosófica nas escolas que trabalham com crianças $e$ adolescentes.

Por fim, gostaria de agradecer ao Felipe Xavier Viégas que foi nosso colaborador nos três primeiros números da RESAFE, como elaborador das páginas de internet. Ele nos acompanhou com um trabalho bonito e disposto. Em função de outras atividades que o chamaram ele teve que nos deixar. Dou, em nome da RESAFE, as boas vindas a nosso novo elaborador das páginas, Pedro Henrique, desde já agradecendo a sua participação neste número - espero que a primeira dentre muitas.

Fico feliz de mais uma vez lançarmos olhares múltiplos na esperança de multiplicar olhares.

wanderson flor do nascimento editor 